\title{
An investigation of waiting times of patients admitted to the general surgery clinic from an emergency department
}

\author{
Acil servisten genel cerrahi kliniğine yatırılan hastaların \\ bekleme sürelerinin incelenmesi
}

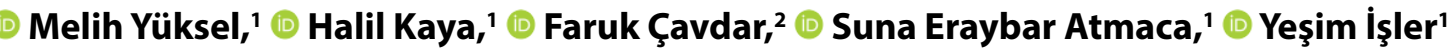 \\ 'Department of Emergency Medicine, Health Sciences University, Bursa Yüksek Ihtisas Training and Research Hospital, Bursa, Turkey \\ 2Department of General Surgery, Health Sciences University, Bursa Yüksek İhtisas Training and Research Hospital, Bursa, Turkey
}

\begin{abstract}
Introduction: The study aimed to determine the waiting times of the patients admitted to the general surgery clinic from an emergency department and to investigate the effectiveness of services. Methods: 1564 patients over the age of 18 admitted to the General Surgery Clinic from the emergency department of Health Sciences University Bursa Yuksek IhtisasTraining and Research Hospital between 01.01.2018 and 31.12.2018 were included. Age, gender, admission and waiting times, the diagnoses, and surgical history or hospitalization were retrospectively analyzed. The difference between the admission time to the emergency department and the admission time to the general surgery clinic was accepted as waiting time.

Results: $56 \%$ of the patients ( $n: 876$ ) were male and the mean age was 49.9. The mean waiting time in the emergency department was 440.85 minutes and the mean hospital stay was 4.67 days. The minimum waiting time was in abdominal trauma (249.49 min) whereas the longest waiting time was in mesenteric ischemia (732.27 min) in the emergency department.
\end{abstract}

Discussion and Conclusion: We believe that having a separate and senior team in emergency services of work-intensive departments such as general surgery will contribute to shortening waiting times and providing faster and more effective health care.

Keywords: Emergency medical service; waiting time; general surgery; consultation.

Emergency departments (EDs) have an important role in Ehealth care organizations globally in terms of enabling urgent medical care for cases needing immediate attention. ${ }^{[1]}$ However, EDs' services may be problematic because of the high number of patients and the demanding nature of the profession. This might
Özet

Amaç: Bu çalışmanın amacı acil servise başvurup genel cerrahi kliniğine yatırılan hastaların acil serviste bekleme sürelerinin belirlenmesi ve sağlık hizmetlerinin etkinliğini araştırmaktır.

Gereç ve Yöntem: 01.01.2018 ile 31.12.2018 tarihleri arasında Sağlık Bilimleri Üniversitesi Bursa Yüksek İhtisas Eğitim ve Araştırma Hastanesi Acil Servisten Genel Cerrahi Kliniğine yatırılan 18 yaş üstü toplam 1564 hasta dahil edilmiştir. Hastaların yaş, cinsiyet, acil servise başvuru zamanları, acil serviste bekleme süreleri, hangi tanılar ile yattı̆̆ı, cerrahi bir işlem geçirip geçirmediği ve yatış süreleri retrospektif olarak incelendi. Hastanın acil servise ilk başvuru saati ile genel cerrahi kliniğine yattığı saat arasındaki fark bekleme süresi olarak kabul edildi.

Bulgular: Hastaların, \% 56'sı ( n:876) erkek olup, ortalama yaş 49,9 olarak saptandı. Hastaların acil serviste ortalama bekleme süresi 440.85 dakika olup ortalama hastanede yatış süreleri ise 4.67 gün olarak saptanmıştır. Acil serviste hastaların tanısına göre en az bekleme süresi $249.49 \mathrm{dk}$ ile batın travmaları, en uzun bekleme süresi ise $732.27 \mathrm{dk}$ ile mezenter iskemi olarak saptanmıştır.

Sonuç: Genel cerrahi gibi iş yükü yoğun olan bölümlerin acil servis konsültasyonlarında ayrı ve kıdemli bir ekip bulundurmasının, bekleme sürelerinin kısalmasına, daha hızlı ve etkin bir sağlık hizmeti sağlayacağını düşünmekteyiz.

Anahtar Sözcükler: Acil servis; bekleme süresi; genel cerrahi; konsültasyon.

result in an increase in waiting times, improper treatment, wasting the economic resources, and ethical considerations. ${ }^{[2]}$ The intensity of the emergency department particularly affects the quality of the health services, the satisfaction of the patients and the probability of the health workers' making mistakes..$^{[3]}$ 
Patients admitted to the emergency departments vary widely. These admissions may be a simple medical condition or a lifethreatening condition. One of the most common complaints of patients admitted to emergency services is abdominal pain. ${ }^{[4]}$ In addition, blunt or penetrating abdominal trauma are among other reasons for admission to emergency services.

In this study, the waiting times of the patients who were admitted to a general emergency clinic with abdominal pain and blunt or penetrating abdominal trauma after the physical examination, laboratory and imaging tests were evaluated.

\section{Materials and Method}

A total of 1564 patients over the age of 18 who were admitted to the General Surgery Clinic from the Emergency Department of Health Sciences University Bursa Yuksek IhtisasTraining and Research Hospital between 01.01.2018 and 31.12.2018 were included. The study was conducted retrospectively and approval was obtained from the local ethics committee (2011KAEK-25 2019/04-07). The difference between the time of the first admission to the emergency department and the time of admission to the general surgery clinic was calculated as the waiting time. In addition, age, gender, time of admission to the emergency department, diagnosis, surgical history, and length of stay were evaluated.

\section{Statistical Analysis}

The data were analyzed using SPSS for Windows (21.0) software. All values were expressed as mean \pm standard deviation (SD). Data were analyzed via Student's t-test. One-way Anova test was conducted to investigate whether there was a significant difference between independent groups according to the mean. The post-hoc Tukey test was used to investigate the source of differences between the groups. Parametric variables were analyzed by Pearson test while non-parametric variables were analyzed by Spearmen test. $P$ values $<0.05$ were considered significant. Results were given in the $95 \%$ confidence interval.

\section{Results}

1564 patients were included in the study. $56 \%$ of the patients ( $n: 876)$ were male and the mean age was 49.9 (min: 18, max: 95). $70.2 \%$ of the patients admitted to the emergency department on weekdays and $57.5 \%$ on $16-08$ shifts. Surgical intervention was performed in $54.2 \%$ of the patients and $93.7 \%$ were discharged with healing. The mean waiting time of the patients in the emergency department was 440.85 minutes and the mean hospital stay was 4.67 days (Tables 1, 2).

The most common diagnosis was acute appendicitis (33.7\%) while the lowest diagnosis was volvulus-invagination (0.6\%). According to the diagnosis of patients in the emergency department, the minimum waiting time was $249.49 \mathrm{~min}$. in abdominal trauma and the longest waiting time was $732.27 \mathrm{~min}$ in mesenteric ischemia (Table 3).

There was a significant difference between the waiting times

\section{Table 1. Demographic data}

\begin{tabular}{lcc} 
Variables & $\mathbf{n}$ & $\%$ \\
\hline $\begin{array}{lcc}\text { Gender } \\
\text { Male }\end{array}$ & 876 & 56.0 \\
Female & 688 & 44.0 \\
Treatment type & & \\
$\quad$ Surgical & 847 & 54.2 \\
$\quad$ Medical & 717 & 45.8 \\
The last condition & & \\
Treatment rejection & 12 & 0.8 \\
Healing & 1465 & 93.7 \\
Exitus & 49 & 3.1 \\
Transfer to another section & 2 & 0.1 \\
Referral & 6 & 0.4 \\
Other & 3 & 0.2 \\
Discharged & 27 & 1.7 \\
Total & 1564 & 100 \\
\hline
\end{tabular}

Table 2. Mean age, waiting time and length of stay

\begin{tabular}{lccc} 
& Age & Waiting time & Length of stay \\
\hline Mean & 49.9373 & 440.8574 & 4.6777 \\
Median & 49.0000 & 354.0000 & 3.0000 \\
Std. deviation & 20.26005 & 380.12220 & 5.19717 \\
Range & 78.00 & 7378.00 & 98.00 \\
Minimum & 18.00 & 1.00 & 1.00 \\
Maximum & 95.00 & 7379.00 & 99.00 \\
\hline
\end{tabular}

and admission times in the emergency department (Weekdays-Weekend and Public Holidays) due to the weekdays' admissions $(p<0,01$ One-Way Anova and Post-Hoc Tukey Test) (Table 4).

There was a significant difference between waiting time in the emergency department and patient diagnoses due to abdominal trauma ( $p<0.01$ One-Way Anova and Post-Hoc Tukey Test) (Table 5).

In the Spearman test for nonparametric correlation, there was a correlation between the duration of waiting in the emergency department and the treatment type $(p=0.005),(r=0.71)$, and the waiting time in the emergency department and admission time $(\mathrm{p}=0.00),(\mathrm{r}=-1.37)$ (Table 6$)$.

In the Pearson test for parametric correlation, no correlation was found between the waiting time in the emergency department and the age of the patients and the duration of hospitalization.

\section{Discussion}

Length of stay is considered as a significant marker which shows the quality of services in emergency departments. ${ }^{[5]} \mathrm{It}$ was found in several studies in the literature that the number of the patients is related to the length of stay ${ }^{[6]}$ In the studies 
Table 3. Mean waiting time and frequency of variables

\section{Frequency}

Percent

Waiting time in emergencies mean (Dk)

Standard deviation

Diagnosis

Acute appendicitis

Acute cholecystitis

Acute pancreatitis

Abdominal trauma

Abdominal-anorectal abscess

GIS bleeding

GIS malignancy

GIS perforation

Hernia

lleus

Abdominal pain etyo-IBD

Mesenteric ischemia

Post-op complication

Volvulus-Invagination

Other

\section{Admission time}

Weekdays

Weekend

Public holiday

Working time

08:00-16:00

16:00-08:00

Total

\begin{tabular}{cc}
527 & 33.7 \\
191 & 12.2 \\
142 & 9.1 \\
89 & 5.7 \\
24 & 1.5 \\
30 & 1.9 \\
57 & 3.6 \\
91 & 5.8 \\
77 & 4.9 \\
146 & 9.3 \\
108 & 6.9 \\
11 & 0.7 \\
20 & 1.3 \\
9 & 0.6 \\
42 & 2.7 \\
& \\
1098 & 70.2 \\
403 & 25.8 \\
63 & 4.0 \\
& \\
665 & 42.5 \\
899 & 57.5 \\
1564 & 100 \\
\hline & \\
\hline &
\end{tabular}

432.34
472.40
487.37
249.49
459.50
517.67
424.26
384.40
400.58
478.38
537.57
732.27
440.05
382.56
363.14

466.86
384.05
351.05

301.20

369.08

389.59

208.85

490.42

375.52

467.59

226.44

838.46

286.06

381.20

469.51

387.05

372.91

403.42

401.39

324.66

259.56

412.98

353.86

380.12

GIS: Gastrointestinal system; IBD: Inflammatory bowel disease.

Table 4. Comparison of emergency service admission time and waiting times Tukey HSD

\begin{tabular}{|c|c|c|c|c|c|}
\hline (I) Time of arrival & (J) Time of arrival & Mean difference (I-J) & Std. error & Sig. & $95 \% \mathrm{Cl}$ \\
\hline Weekend & $82.81103^{*}$ & 22.02780 & 0.001 & 31.1351 & 134.4870 \\
\hline \multicolumn{6}{|l|}{ Weekend } \\
\hline Weekdays & $-82.81103^{*}$ & 22.02780 & 0.001 & -134.4870 & -31.1351 \\
\hline Weekdays & $-115.81304^{*}$ & 48.99808 & 0.048 & -230.7597 & -0.8663 \\
\hline Weekend & -33.00201 & 51.23946 & 0.796 & -153.2069 & 87.2028 \\
\hline
\end{tabular}

*:The mean difference is significant at the 0.05 level. $\mathrm{Cl}$ : Confidence interval.

conducted in the USA regarding the intensity of the emergency department and the waiting period of the patients in the emergency departments, the greatest problem with emergency services has been reported to be the overcrowding of patients. ${ }^{[7]}$ Overcrowding in EDs is an important issue needs to be solved in terms of a shortfall in supply and resources, which may result in long waiting times and having improper treatment. A study has shown that ED visit rates and ED crowding are increasing worldwide, except in Scandinavian countries. ${ }^{[8]}$ In our country, due to the prolongation of ED crowding and waiting time, the Ministry of Health has issued a circular to prevent hospitalization in elective conditions for cases longer than 4 (four) hours even if longer than 8 (eight) hours hospitalization for observation and follow-up is decided. ${ }^{[9]}$

In a study conducted in our country regarding the waiting 
Table 5. Comparison of emergency waiting time and diagnosis Tukey HSD ${ }^{a, b}$

\begin{tabular}{lccc} 
Tanı & N & \multicolumn{2}{c}{$\begin{array}{c}\text { Subset for } \\
\text { alpha }=\mathbf{0 . 0 5}\end{array}$} \\
\cline { 2 - 4 } & & $\mathbf{1}$ & $\mathbf{2}$ \\
\hline Abdominal trauma & 89 & 249.4944 & \\
Other & 42 & 363.1429 & \\
Volvulus-invagination & 9 & 382.5556 & \\
GIS perforation & 91 & 384.3956 & \\
Hernia & 77 & 400.5844 & \\
GIS malignancy & 57 & 424.2632 & \\
Acute appendicitis & 527 & 432.3397 & 432.3397 \\
Post-op complication & 20 & 440.0500 & 440.0500 \\
Abdominal-anorectal abscess & 24 & 459.5000 & 459.5000 \\
Acute cholecystitis & 191 & 472.3979 & 472.3979 \\
ileus & 146 & 478.3836 & 478.3836 \\
Acute pancreatitis & 142 & 487.3662 & 487.3662 \\
GIS bleeding & 30 & 517.6667 & 517.6667 \\
Abdominal pain etyo-IBD & 108 & 537.5741 & 537.5741 \\
Mesenteric ischemia & 11 & & 732.2727 \\
Sig. & & 0.094 & 0.064 \\
\hline
\end{tabular}

Means for groups in homogeneous subsets are displayed. a: Uses harmonic mean sample size $=34.573$. b: The group sizes are unequal. The harmonic mean of the group sizes is used. Type I error levels are not guaranteed. GIS: Gastrointestinal system; IBD: Inflammatory bowel disease. times in the emergency departments, the mean hospitalization period was $26.5 \pm 22.3$ hours in patients who needed Intensive Care Unit (ICU) and 31.2 \pm 23.3 hours in patients who did not need ICU. In this study, the mean waiting time of patients admitted to the general surgery service was found to be 19.5 hours. ${ }^{[10]}$ In our study, the mean waiting time of patients admitted to the general surgery service was 440 minutes in emergencies. Although the mean waiting time was less than the other study compared, it was long in terms of the targeted time. In our study, the minimum waiting time was in abdominal trauma, while the maximum waiting time was in mesenteric ischemia. Mesenteric ischemia is relatively more difficult to diagnose than other acute abdominal pain. The fact that the findings are sometimes nonspecific, the patients are generally elderly and have co-morbid diseases may make the diagnosis difficult. ${ }^{[1]]}$ In addition, we think that the intensity of the emergency department, the inexperience of the general surgery consultant, and late arrival to the consultation because of being in the surgical team or providing polyclinic service at the same time are some of the reasons for long waiting time. In another study conducted in our country, it was found that the general surgery was found to have the latest arrival time for consultation. In this study, the mean response time of general surgeons to the consultation was 44:17 min. ${ }^{[12]}$ In a study conducted by Dönmez et al., the duration of the consultation was investigated and it was determined that the maximum duration of the consultation was 222 minutes in thoracic surgery

Table 6. Nonparametric correlations table of variables

\begin{tabular}{|c|c|c|c|c|c|c|}
\hline & $\begin{array}{c}\text { Last } \\
\text { condition }\end{array}$ & $\begin{array}{c}\text { Treatment } \\
\text { type }\end{array}$ & Diagnosis & $\begin{array}{l}\text { Working } \\
\text { time }\end{array}$ & $\begin{array}{l}\text { Time of } \\
\text { arrival } \\
\text { service }\end{array}$ & $\begin{array}{l}\text { Waiting times } \\
\text { at the emergency }\end{array}$ \\
\hline \multicolumn{7}{|l|}{ Spearman's rho } \\
\hline \multicolumn{7}{|l|}{ Last condition } \\
\hline Correlation coefficient & 1 & 0.025 & $0.139^{* *}$ & -0.021 & $-0.073^{* *}$ & 0.018 \\
\hline Sig. (2-tailed) & . & 0.315 & 0 & 0.399 & 0.004 & 0.466 \\
\hline \multicolumn{7}{|l|}{ Treatment type } \\
\hline Correlation coefficient & 0.025 & 1 & $0.408^{* *}$ & 0 & -0.021 & $0.071^{* *}$ \\
\hline Sig. (2-tailed) & 0.315 & . & 0 & 0.989 & 0.408 & 0.005 \\
\hline \multicolumn{7}{|l|}{ Diagnosis } \\
\hline Correlation coefficient & $0.139^{* *}$ & $0.408^{* *}$ & 1 & 0 & 0.025 & -0.007 \\
\hline Sig. (2-tailed) & 0 & 0 & . & 0.988 & 0.32 & 0.769 \\
\hline \multicolumn{7}{|l|}{ Working time } \\
\hline Correlation coefficient & -0.021 & 0 & 0 & 1 & $0.072^{* *}$ & 0.016 \\
\hline Sig. (2-tailed) & 0.399 & 0.989 & 0.988 & . & 0.005 & 0.521 \\
\hline \multicolumn{7}{|l|}{ Time of arrival } \\
\hline Correlation coefficient & $-.073^{* *}$ & -0.021 & 0.025 & $0.072^{* *}$ & 1 & $-0.137^{* *}$ \\
\hline Sig. (2-tailed) & 0.004 & 0.408 & 0.32 & 0.005 & . & 0 \\
\hline \multicolumn{7}{|c|}{ Waiting time at the emergency service } \\
\hline Correlation coefficient & 0.018 & $0.071^{* *}$ & -0.007 & 0.016 & $-0.137^{* *}$ & 1 \\
\hline Sig. (2-tailed) & 0.466 & 0.005 & 0.769 & 0.521 & 0 & . \\
\hline
\end{tabular}

**: Correlation is significant at the 0.01 level (2-tailed). 
and 196 minutes in general surgery. ${ }^{[13]}$ The peak hours of emergency services are usually evening hours. Especially most of the admissions are between 18: 00-24: $00 .^{[5,14]}$ Looking at these studies, it is normally expected that waiting times will be longer during peak hours of emergency services. However, the highest waiting period in our study was determined as 08: 0016: 00 . This finding was also statistically significant. We believe that this depends on the late consultation period. Because the consultant physicians can also be in the surgical team or they can consult not only in the emergency department but also in other departments. In a study on the treatments applied to patients admitted to the general surgery service, it was reported that 450 of 585 patients underwent surgery and 145 patients had medical treatment. In our study, 847 (54.2\%) patients underwent surgery. ${ }^{[15]}$ We believe that the reason for the lower rate of surgical intervention compared to the other study was because cases with cholecystitis, ileus and pancreatitis were more likely to receive medical treatment.

\section{Limitations}

As this study was conducted retrospectively, the difference between admission time to the emergency department and admission time to the general surgery clinic was calculated. However, how long the patients waited in the triage area and when the consultant physician was notified and when the consultant physician came to the emergency room could not be calculated exactly. This might affect the waiting time. Therefore, this situation may be investigated in detail in prospective studies.

As a result, crowded emergency services and long waiting times cause many problems for the quality of emergency services in developing countries. New health policies need to be developed in this regard. In addition, we believe that having a separate and senior team in emergency departments of workintensive departments such as general surgery will contribute to shortening waiting times and providing faster and more effective health care.

Conflict of interest: There are no relevant conflicts of interest to disclose.

Funding: This study is not supportive. The authors disclosed that they did not receive any grant during conduction or writing of this study.

\section{References}

1. McHale P, Wood S, Hughes K, Bellis MA, Demnitz U, Wyke S. Who uses emergency departments inappropriately and when - a national cross-sectional study using a monitoring data system. BMC medicine. 2013;11:258. Epub 2013/12/18. doi: 10.1186/17417015-11-258. PubMed PMID: 24330758; PubMed Central PMCID: PMCPMC3886196.
2. Hoot NR, Aronsky D. Systematic review of emergency department crowding: causes, effects, and solutions. Annals of emergency medicine. 2008;52(2):126-36. Epub 2008/04/25. doi: 10.1016/j.annemergmed.2008.03.014. PubMed PMID: 18433933.

3. Akkaya EG, Bulut M, Akkaya C. The factors affecting the level of patients' satisfaction of the applicants for emergency service/Acil servise basvuran hastalarin memnuniyetini etkileyen faktorler. Turkish Journal of Emergency Medicine. 2012;12(2):62-9.

4. Stone R. Acute abdominal pain. Lippincott's primary care practice. 1998;2(4):341-57. Epub 1998/08/26. PubMed PMID: 9709080.

5. McCarthy ML, Zeger SL, Ding R, Levin SR, Desmond JS, Lee J, et al. Crowding delays treatment and lengthens emergency department length of stay, even among high-acuity patients. Annals of emergency medicine. 2009;54(4):492-503.e4. Epub 2009/05/09. doi: 10.1016/j.annemergmed.2009.03.006. PubMed PMID: 19423188.

6. Rathlev NK, Chessare J, Olshaker J, Obendorfer D, Mehta SD, Rothenhaus $\mathrm{T}$, et al. Time series analysis of variables associated with daily mean emergency department length of stay. Annals of emergency medicine. 2007;49(3):265-71. Epub 2007/01/17. doi: 10.1016/j.annemergmed.2006.11.007. PubMed PMID: 17224203.

7. Trzeciak S, Rivers EP. Emergency department overcrowding in the United States: an emerging threat to patient safety and public health. Emergency medicine journal : EMJ. 2003;20(5):402-5. Epub 2003/09/05. doi: 10.1136/emj.20.5.402. PubMed PMID: 12954674; PubMed Central PMCID: PMCPMC1726173.

8. Pines JM, Hilton JA, Weber EJ, Alkemade AJ, Al Shabanah $H$, Anderson $P D$, et al. International perspectives on emergency department crowding. Academic emergency medicine : official journal of the Society for Academic Emergency Medicine. 2011;18(12):1358-70. Epub 2011/12/16. doi: 10.1111/j.15532712.2011.01235.x. PubMed PMID: 22168200.

9. 2018. Available from: https://www.saglik.gov.tr/TR,11321/ yatakli-saglik-tesislerinde-acil-servis-hizmetlerinin-uygulama-usul-ve-esaslari-hakkinda-teblig.html

10. Yakar Ş. Acil Serviste Hastaneye Yatış için Bekleyen Hastaların Incelenmesi. [Uzmanlık Tezi]. In press 2015.

11. Oldenburg WA, Lau LL, Rodenberg TJ, Edmonds HJ, Burger CD. Acute mesenteric ischemia: a clinical review. Archives of internal medicine. 2004;164(10):1054-62.

12. Karakaya Z, Gokel Y, Acikalin A, Karakaya O. [Evaluation of the process and effectiveness of consultation system in the Department of Emergency Medicine]. Ulusal travma ve acil cerrahi dergisi $=$ Turkish journal of trauma \& emergency surgery: TJTES. 2009;15(3):210-6. Epub 2009/06/30. PubMed PMID: 19562540.

13. Dönmez SS, Durak VA, Torun G, Köksal Ö, Aydin Ş. Acil Serviste Gerçekleştirilen Konsültasyon Sürecinin İncelenmesi. Uludağ Üniversitesi Tıp Fakültesi Dergisi. 2017;43(1):23-8.

14. Kılıçaslan I, Bozan H, Oktay C, Göksu E. Türkiye'de acil servise başvuran hastaların demografik özellikleri. Türkiye Acil Tıp Dergisi. 2005;5(1):5-13.

15. Aydin O. Acil Servisten Genel Cerrahiye Konsulte Edilen OlguIarın Tanısal Analizi. Kırıkkale Üniversitesi Tıp Fakültesi Dergisi. 2014;16(3):1-3. 